\title{
Development of Children's Literature Book Based on Primary School Students' Ecoliteration
}

\author{
Tatat Hartati ${ }^{1}$, Eli Nurlela Andriani ${ }^{2}$, Nana Supriatna ${ }^{3}$, Risma Nuriyanti ${ }^{4}$ \\ 1,2,3 Universitas Pendidikan Indonesia \\ ${ }^{4}$ Institut Pendidikan Indonesia \\ tatat@upi.edu
}

Article History

accepted 05/11/2020

approved $10 / 11 / 2020$

published 01/02/2021

\begin{abstract}
Lack of student interest in literature is due to the low literacy of students. Therefore, one of the ways to improve the students' literacy and ecological awareness is through children's literature. Hence, Ecoliteration-based children's literature books are considered to be used as learning support books, media as well as sources of learning Bahasa for elementary schools. This study aimed to determine the design of eco-literation-based children's literature models for elementary school students.. This study adopted a development research wich Educational Design Research (EDR) was applied. This study involved lecturers, practitioners/ experts, and elementary school, teachers. The developed book contained some materials namely Bahasa, Science, and Social Sciences for four grade students by proposing a theme of "Peduli Terhadap makhluk Hidup (Caring for Sentient Beings)", added with Basic Competence from 2013 curriculum of Environmental Education lesson (PLH) and eco-literation competencies (Head, Heart, Hands, and Spirit). This study has 3 major findings: (1) the researchers successfully created a eco-literation-based children's literature model book for elementary school pupils entitled "The Mystery of the Disappearance of A Friend" and "The Mystery of the Butterfly" (2) This study found the suitable characteristics of eco-literation book for Elementary School Students, (3) There are positive response towards these kinds of literature from the experts and the teachers.
\end{abstract}

Keywords: ecological literacy, eco-literation-based children's literature book; educational design research, elementary school students

\begin{abstract}
Abstrak
Kurangnya minat siswa terhadap sastra berakibat pada rendahnya literasi siswa. Salah satu cara untuk meningkatkan literasi dan kesadaran ekologis siswa adalah melalui karya sastra anak. Oleh karena itu, buku sastra anak berbasis ekoliterasi dianggap dapat digunakan sebagai buku penunjang pembelajaran, media serta sumber belajar bahasa bagi sekolah dasar. Penelitian ini bertujuan untuk mengetahui desain model sastra anak berbasis eko-literasi untuk siswa sekolah dasar. Penelitian ini mengadopsi penelitian pengembangan yang menggunakan Educational Design Research (EDR). Penelitian ini melibatkan dosen, praktisi / ahli, dan sekolah dasar, guru. Buku yang dikembangkan berisi materi Bahasa, IPA, dan IPS untuk siswa kelas IV SD dengan mengusung tema "Peduli Terhadap makhluk Hidup", ditambah dengan Kompetensi Dasar dari kurikulum 2013 pelajaran Pendidikan Lingkungan (PLH). dan kompetensi eko-literasi (Kepala, Hati, Tangan, dan Jiwa). Penelitian ini memiliki 3 temuan utama: (1) peneliti berhasil membuat buku model sastra anak berbasis eko-literasi untuk siswa sekolah dasar berjudul "Misteri Hilangnya Teman" dan "Misteri Kupu-Kupu" (2 Studi ini menemukan karakteristik buku eko-literasi yang sesuai untuk siswa SD, (3) Ada respon positif dari para ahli dan guru terhadap jenis literatur tersebut.
\end{abstract}

Kata kunci: literasi ekologis, buku sastra anak berbasis eko-literasi; penelitian desain pendidikan, siswa sekolah dasar

Social, Humanities, and Education Studies (SHEs): Conference Series https://jurnal.uns.ac.id/shes

p-ISSN 2620-9284 e-ISSN 2620-9292 


\section{PENDAHULUAN}

Program International Reading Literacy Study (PIRLS) tahun 2011 mengungkapkan, literasi Indonesia masih rendah. Untuk 49 negara yang disurvei. Indonesia menempati urutan ke-40 41 dari 45 negara dengan kondisi Distribusi Prestasi Membaca (DPM) lebih rendah dari skala 500 (titik tengah / skala standar PIRLS) (Mullis et al., 2012; Baswedan, 2014). Pada tahun 2015, PISA (Program for International Student Assessment) dan TIMSS (Trends in International Mathematics and Science Study) melakukan penilaian lanjutan, kedua institusi ini menyimpulkan bahwa kemampuan literasi siswa Indonesia masih rendah yaitu menduduki peringkat ke-62 dari 70 negara yang disurvei. (dilaporkan dari republika.co.id). Apalagi Program Penilaian Nasional Indonesia (INAP) (dilaporkan di puspendik.kemdikbud.go. id) melakukan survei pada tahun 2016 dan menemukan bahwa literasi siswa Indonesia $46,83 \%$ siswa memiliki literasi rendah kurang, dan seterusnya $47,11 \%$ cukup, $6,06 \%$ baik. Selanjutnya terdapat gap perolehan skor nasional berdasarkan konten sastra dan non sastra di Indonesia berdasarkan INAP tahun 2016. Hasil penelitian menunjukkan bahwa domain konten sastra memperoleh skor rata-rata 27,65 , sedangkan domain konten non sastra memperoleh skor rata-rata 27,65, sedangkan domain konten non sastra. memperoleh skor lebih tinggi yaitu 43,34 dari jumlah total 95 pertanyaan. Skor ini menunjukkan rendahnya minat dan pemahaman siswa terhadap sastra tertentu. Berdasarkan LSI (Lingkaran Survei Indonesia), minat terhadap sastra Indonesia hanya 6,2\% (Denny, 2017). Mustafa (2008, hlm. 130) menyimpulkan bahwa kesusastraan berkontribusi pada proses membaca karena maknanya, dengan kata lain,

Materi utama pustaka adalah lingkungan (lovino, 2012). Cerita anak-anak biasanya menceritakan tentang seseorang atau kejadian sehari-hari, yang dapat diterima dengan logika mereka (Polkinghorne, D.E, 1995). Secara logika, anak memiliki kemampuan intelektual dan emosional dalam memahami hal-hal tentang kehidupan manusia, hubungan antar manusia, interaksi manusia dengan makhluk Tuhan yang lain, termasuk hubungan manusia dengan alam semesta (Hasanuddin, 2015, h. 3). Selain itu menurut Costanza dalam Supriatna (2016: 108) "Manusia adalah bagian dari alam, tidak lepas darinya" (). Dengan demikian salah satu indikator literasi sastra (literate) adalah anak dapat mengambil sikap dan memaknai lingkungannya. Dengan kata lain sastra dapat mendorong terciptanya kecerdasan lingkungan (ecological intelligence), atau yang dikenal dengan istilah eko-literasi (Lanter, E., Watson, LR, Erickson, KA, \& Freeman, D.2012).

Kecerdasan ekologis merupakan kecerdasan yang menggambarkan kemampuan atau kapasitas seseorang dalam melakukan tindakan yang berkaitan dengan aspek ekologi yaitu pelestarian alam (Supriatna, 2016, h. 24). Isi dari ekoliterasi menekankan pengalaman siswa dan berpusat pada siswa daripada kognitif (Carver, 1996; Carver 1997; Corney \& Reid, 2007). Ward \& Dubos (1972) menyatakan bahwa bumi adalah satu-satunya, dan tentunya kelangsungan hidup manusia sangat bergantung pada upaya pelestarian dan pelestarian lingkungan. Karena hanya ada satu bumi, kecerdasan ekologi ini sangat penting untuk ditumbuhkan pada siswa sekolah dasar untuk menghindari kerusakan yang dikemukakan oleh Supriatna (2016, h. 111) sebagai "degradasi lingkungan" atau "krisis lingkungan".

Fenomena alam dan permasalahan sosial yang terjadi disekitar kita seperti banjir, gempa bumi, permasalahan sampah, banjir, kemacetan, asap, penggundulan hutan, penyempitan lahan, konsumtif, pola hidup tidak sehat, dan cara pandang lain harus dikenalkan kepada anak sebagai sosial karena permasalahan berdampak pada penurunan literasi ekologi (Goleman, 2009, hlm. 13-14). Sayangnya, pengenalan ekologi belum ditanggapi dengan serius. Hal ini tercermin dari kurikulum pendidikan yang diterapkan dan minimnya penelitian di Indonesia yang menyinggung tentang bagaimana meningkatkan kecerdasan ekologi siswa. Penelitian ini sangat penting 
karena bertujuan untuk mengembangkan model buku berbasis eko-literasi. Dengan berkembangnya buku sastra anak berbasis eko-literasi,

Penelitian terkait sebelumnya oleh Abdurrohim (2016) tentang perkembangan eko-literasi dalam pembelajaran IPS dengan teknik modeling di sekolah dasar menunjukkan bahwa penerapan teknik modeling dapat mengembangkan sikap ekoliterasi siswa. Namun pembelajaran dengan teknik pemodelan ini kurang diminati siswa. Karena itu tidak menyemangati siswa. Oleh karena itu, perlu adanya pembelajaran eko-literasi dengan menerapkan model pembelajaran yang bervariasi agar dapat meningkatkan daya tarik siswa. Nugraha (215) mengemukakan bahwa siswa akan merasa lebih tertarik dan merasakan pembelajaran yang bermakna dengan mengalami sendiri daripada dengan belajar secara langsung. Kalimat yang membingungkan penelitian eko-literasinya dengan metode field trip telah meningkatkan pemahaman siswa tetapi kesadaran dan penerapannya. Merefleksikan studi sebelumnya.

Penelitian ini menggunakan metode Education Design Research (EDR). Mengingat masih jarangnya Sastra atau Buku Anak, khususnya Sastra anak khusus bertema ekologi yang disajikan sesuai dengan karakter anak usia sekolah dasar (memperhatikan aspek perkembangan bahasa, kognitif, kepribadian dan karakteristik sosial anak. ). Selain itu, buku juga merupakan media yang paling efektif dalam mengenalkan sastra dan ekologi kepada siswa, karena buku mampu menyimpan informasi selama bertahun-tahun, jika dilupakan dapat dibuka kembali sehingga isinya akan selalu lestari selama buku tersebut dicetak ulang. dan baca. Dengan berkembangnya sastra anak berbasis eko-literasi diharapkan dapat meningkatkan kualitas hidup anak didik. kecerdasan ekologi (eco-literacy) terhadap fenomena di sekitarnya, untuk menghasilkan ide atau solusi (pemecahan masalah) bagi masalah di lingkungan sekitarnya. Dalam penerapannya nantinya, karya sastra anak berbasis eko literasi ini dapat dicetak, direproduksi, dan digunakan sebagai penunjang dan atau media atau bahan ajar untuk pembelajaran (terutama pembelajaran PLH dan bahasa Indonesia), sehingga masyarakat melek masalah lingkungan ( literasi lingkungan)

Tujuan penelitian ini adalah untuk mengetahui landasan teori penyusunan, pengembangan, dan perancangan buku sastra anak berbasis eko-literasi untuk siswa sekolah dasar.

\section{METODE}

Penelitian ini menggunakan metode Education Design Research (EDR). Menurut Barab dan Squire (dalam Lidinillah, 2014, van den Akker et al., 2006, h. 5) EDR merupakan rangkaian pendekatan dengan tujuan menghasilkan teori, artefak, dan model praktis baru yang menjelaskan dan berpotensi mempengaruhi pembelajaran dengan pengaturan naturalistik. Dalam penelitian ini, perancangan menggunakan empat tahap (1) identifikasi masalah, 2) perancangan, 3) pengembangan dan 4) refleksi:

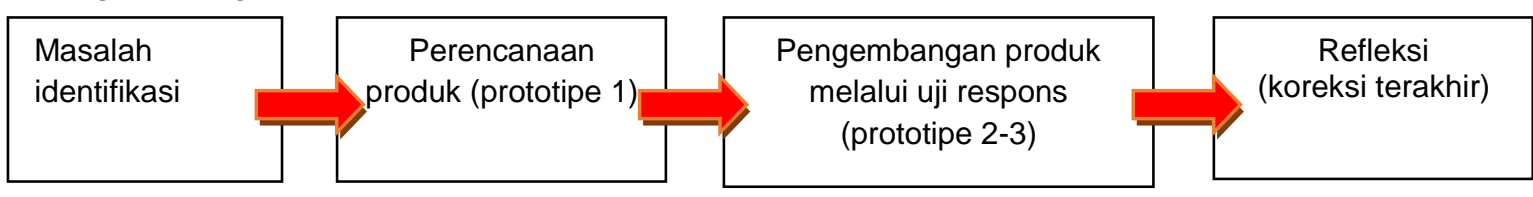

Bagan 1 Tahapan Penelitian Desain Pendidikan

Untuk lebih jelasnya pada bagian mengidentifikasi masalah peneliti mengamati tentang minat sastra dan kecerdasan ekologi serta mengkaji literatur termasuk analisis buku sastra anak berbasis eko-literasi yang tersedia di lapangan. Selanjutnya 
menentukan model sastra anak berdasarkan eko-literasi yang akan dikembangkan, menentukan kompetensi dasar yang akan dipilih untuk model perancangan, menentukan isi eko-literasi yang akan dikembangkan. Selanjutnya merancang buku eko-literasi sastra anak berupa prototipe 1 dan melakukan uji coba, menganalisis bahasa, konteks, kesesuaian dengan kurikulum dan isi karakter yang diperbandingkan pada model awal. Setelah itu,

Penelitian ini melibatkan dosen, pakar, dan guru siswa kelas empat. Guru berperan sebagai pemberi data (observer) untuk menggali minat sastra dan kecerdasan ekologi siswa. Guru juga memberikan tanggapan tentang buku yang dikembangkan dalam tes terbatas dan luas (resensi buku). Penelitian ini dilakukan di empat sekolah, SDIT Ibadurrohman, SD Baiturrahman, Laboratorium Pilot SD UPI Kampus Tasikmalaya, dan SDIT At-Taufiq Al Islamy. Keempat sekolah tersebut merupakan sekolah negeri yang menggunakan kurikulum 2013.

\section{HASIL DAN PEMBAHASAN}

\section{Rancangan buku literatur berbasis ekologi untuk siswa sekolah dasar}

Dalam proses perancangan buku ada tiga sub kegiatan pokok yang dilakukan. Kegiatan tersebut meliputi studi kurikulum untuk menentukan isi buku, menentukan prinsip desain buku, merancang dan mengembangkan buku.

Berdasarkan kompetensi dasar pendidikan lingkungan dan kompetensi dari The center for eco-literacy, berikut ini terungkapnya indikator-indikator pewarnaan yang terdapat dalam buku sastra anak berbasis eko-literasi.

1. Siswa dapat menyebutkan dua masalah lingkungan. (Kepala 1)

2. Siswa dapat membedakan lingkungan yang rapi dan kotor. (Kepala 1)

3. Siswa dapat membedakan dua jenis sampah (sampah kering dan sampah basah). (Tangan 1)

4. Para siswa mengenal hewan yang identik dengan kotoran. (PLH 2.1)

5. Siswa mengetahui cara membuang sampah dengan benar. (PLH 2.2)

6. Siswa dapat memecahkan masalah lingkungan secara kreatif. (PLH 3.2, Kepala 2)

7. Siswa dapat menyebutkan dua tumbuhan obat yang mengelilingi mereka. (Tangan 2)

8. Mahasiswa mengetahui prestasi Kalpatura dan adiwiyata. (Jantung)

9. Para siswa dapat menyebutkan tiga kebiasaan baik di rumah mereka. (Tangan 1)

10. Siswa mengetahui dua cara merawat tanaman dengan baik. (Roh 1)

11. Siswa dapat menyebutkan dua manfaat tanaman. (Tangan 2)

12. Siswa dapat menyebutkan dua cara mengajak orang lain untuk menjaga lingkungan. (PLH 3.1, Roh 2)

\section{Prinsip desain buku}

Prinsip desain merupakan urutan yang mengarahkan peneliti untuk melakukan pengembangan. Akker (1999, p.9) menyatakan bahwa berikut ini adalah urutanurutannya:

"Jika ingin merancang intervensi $X$ untuk tujuan atau menghasilkan $Y$ dalam konteks $Z$, sebaiknya intervensi dengan karakteristik $A, B$, dan $C$ (penekanan substantif), dan gunakan prosedur $\mathrm{K}, \mathrm{L}$ dan $\mathrm{M}$ (prosedural penekanan), dengan argumen $P, Q$, dan $R$. "

Pernyataan di atas berarti jika peneliti ingin merancang buku sastra berbasis eko-literasi untuk anak dengan tujuan untuk meningkatkan kecerdasan ekologi siswa sekolah dasar (khususnya untuk siswa kelas IV tema 3) maka diperlukan intervensi dengan menggunakan anak. karakteristik buku dengan argumen yang dapat diterima (landasan teori). Adapun uraian dari prinsip desain yang dikembangkan adalah 1) 
model buku sastra anak, 2) tujuan buku sastra anak, 3) konteks buku sastra anak, 4) karakteristik buku sastra anak dan 5) prosedur intervensi dan argumentasi.

\section{Merancang dan mengembangkan buku}

Setelah mempelajari kurikulum dan menentukan prinsip desain, peneliti menulis naskah buku yang berjudul, "Misteri Hilangnya Seorang Tema", dan "Misteri Si Kupukupu" . Kegiatan pengembangan substansi tersebut antara lain pengembangan tujuan pembelajaran, pengembangan karakter dan penokohan, sinopsis cerita, alur cerita, skrip lengkap, storyboard, serta pengembangan tata letak dan ilustrasi.

Proses pengembangan buku sastra anak berbasis eko-literasi dilakukan dengan prosedur lengkap sebagai berikut.

1. Studi pendahuluan (analisis kebutuhan intervensi),

a. Analisis minat siswa kelas empat,

b. Analisis kecerdasan ekologi siswa kelas empat (kesadaran lingkungan siswa),

c. Analisis buku sastra anak berbasis eko-literasi yang tersedia di lapangan.

2. Pengembangan prinsip desain.

3. Perkembangan naskah awal cerita anak sebagai berikut:

a. Perkembangan tujuan pengajaran (TP)

b. Perkembangan karakter dan penokohan

c. Perkembangan arus dan pengaturan (setting)

d. Perkembangan sinopsis cerita

4. Perkembangan naskah lengkap sastra anak

5. Perkembangan storyboard,

6. Perkembangan ilustrasi dan tata letak,

7. Proses penulisan dan perancangan buku sastra anak,

8. Tes respon buku sastra anak melalui bedah buku (terbatas dan luas)

9. Analisis hasil tes respon,

10. Perbaikan buku sastra anak berbasis eko-literasi berdasarkan hasil tes respon,

11. Refleksi buku melalui analisis buku sastra anak berbasis eko-literasi menurut penilaian ahli (ahli), dan

12. Perbaikan buku sastra anak berbasis eko-literasi berdasarkan penilaian para ahli.

Dari urutan proses pengembangan di atas, diusulkan teori desain penyusunan buku anak sebagai berikut:

1. Buku sastra anak berbasis ekoliterasi disajikan dengan konten materi yang telah ditentukan sebelum perancangan (mengacu pada kurikulum dan kompetensi ekoliterasi), sejalan dengan tujuan penelitian dan tujuan pendidikan yang ingin dicapai dari buku tersebut.

2. Sastra anak berbasis ekoliterasi perlu memperhatikan perkembangan anak dari berbagai aspek (aspek bahasa, kognitif, emosional, dan perkembangan sosial). Makanya, buku harus memperhatikan apa kesukaan anak (jenis buku), dalam bentuk apa, dan untuk umur berapa buku itu ditulis. (Ini berdasarkan hasil analisis kesesuaian buku untuk tingkat kelas empat dan kurikulum 2013).

3. Buku sastra anak berbasis ekoliterasi disajikan dengan sampul warna-warni, bentuk yang sesuai dengan kebutuhan siswa (mudah dibaca dan dibawa), bahan yang kuat, dan isi buku yang representatif.

4. Buku sastra anak berbasis ekoliterasi disusun melalui rangkaian prosedur A sampai Z yang telah diatur secara berurutan.

5. Buku literatur anak berbasis ekoliterasi disajikan dengan evaluasi di bagian akhir buku untuk memahami peningkatan pengetahuan dan pemahaman siswa.

6. Buku sastra anak berbasis ekoliterasi disajikan dengan gaya yang menarik dan mendongeng untuk mendukung minat sastra siswa terkait dengan cerita 
petualangan dan imajinasi. (Hal ini ditunjukkan dengan minat siswa pada buku petualangan dan serial detektif).

Pengembangan buku juga didasarkan pada respon guru terhadap hasil desain. Respon tersebut didapat dari tes terbatas dan luas serta resensi buku. Pada uji limit mempengaruhi perbaikan (prototipe 2) dengan memperhatikan respon peserta $(50 \%)$ yaitu:

1. Naskah kedua ceritanya belum muncul secara alami.

2. naskah kedua berisi lebih sedikit humor dan percakapan.

3. Naskah pertama dan kedua tidak merangsang dan melibatkan pembacanya.

4. Skrip pertama dan kedua kurang berisi alur logis.

5. Alur naskah pertama kurang natural dari tokoh cerita.

6. Naskah pertama berisi bentuk fonem yang tidak umum dan tidak terbaca oleh pembaca.

7. Naskah pertama memberikan kurang dari lima kalimat per paragraf.

8. Naskah pertama dan kedua memberikan ilustrasi yang tidak menyenangkan.

9. Skrip pertama memberikan ketidakseimbangan antara jumlah teks dan gambar.

10. Naskah kedua kurang menyatu antara teks dan cerita.

11. Naskah pertama menggunakan lebih sedikit kosakata umum dan membatasi kosakata baru untuk pembaca.

Berdasarkan uji respon luas (prototipe 3), peneliti menemukan kekurangan buku (skor minimal 60\%), sebagai berikut.

1. Naskah pertama dan kedua kurang merangsang dan melibatkan pembaca karena naskah hanya melibatkan pembaca pada lembaran aku bisa, fokus awal pada cerita.

2. Naskah cerita pertama dan kedua tidak dapat diprediksi dengan mudah (artinya cerita memiliki alur yang mengejutkan). Poin ini menunjukkan kekuatan teks, yaitu aliran yang menarik.

3. Naskah pertama dan kedua tidak seimbang antara jumlah teks dan gambar (keterbatasan penulis pada jumlah ilustrasi)

Respon guru mencakup banyak aspek dalam buku cerita anak, mulai dari isi buku, karakteristik buku, dan tata letak secara keseluruhan. Ada tanggapan positif dan tanggapan negatif dari para guru. Pada tes respon luas, guru memberikan respon positif terhadap buku pertama dan kedua. Respon positif dibuktikan dengan respon guru terhadap beberapa kategori yang mendapatkan 100\%. Berikut ini adalah kategorinya:

a. Buku itu sempat memberi kesempatan kepada pembaca untuk berimajinasi.

b. Buku itu telah menggunakan wawasan pembaca.

c. Teks yang digunakan berukuran besar; Oleh karena itu, ada ruang untuk berfoto.

d. Bentuk font di buku itu jelas.

\section{Refleksi ahli buku sastra anak berbasis eko-literasi}

Produk tersebut dikategorikan final (prototipe 3) setelah mendapat saran perbaikan dari uji respon luas. Langkah selanjutnya adalah refleksi para ahli. Refleksi ahli melibatkan dua kasus, yaitu kesesuaian isi karya sastra anak dengan SD tingkat IV dan kesesuaian isi karya sastra anak dengan Kurikulum 2013. Hasil refleksi menunjukkan bahwa buku tersebut sesuai dengan kurikulum kelas IV dan. Komentar ahli terhadap isi buku menunjukkan bahwa buku tersebut mengandung muatan ekoliterasi yang sistematis.

Ada beberapa pertimbangan peneliti serta penulis. Yaitu tentang ejaan, kesalahan ketik, dan penyesuaian gambar, dan kalimat, serta keterbacaan teks. Mengenai ejaan, kesalahan ketik, dan komposisi kata, peneliti mengoreksi kembali 
literatur anak berbasis eko-literasi. Terkait penyesuaian gambar, peneliti meminta pembuat layout untuk memperbaiki ilustrasinya. Sedangkan untuk keterbacaan, peneliti melakukan tes keterbacaan yang digunakan untuk menggoreng dan grafik raygor serta tes keterbacaan kualitatif melalui kategorisasi teks USAID (2015). Hasil uji keterbacaan menunjukkan bahwa teks tersebut sesuai untuk kelas IV karena jumlah kata dan kalimat per halaman yang terdapat dalam buku sudah sesuai.

Berdasarkan muatan eko-literasi dalam buku tersebut, tergambar jelas bahwa buku sastra anak mengandung muatan eko-literasi yang proporsional. Dengan demikian, secara umum dapat disimpulkan bahwa buku tersebut sudah mengandung muatan eko-literasi dan layak untuk dicetak serta digunakan sebagai buku pendukung pembelajaran di kelas IV. Lebih lanjut, buku berjudul "The Mystery of the Lost Friends" dan "Mystery of the Butterflies" menjadi sumber belajar baru bagi siswa SD kelas IV, khususnya menambah daftar referensi di bidang eko pedagogi dan sastra.

Hasil penelitian menunjukkan minat literatur siswa dan kesadaran ekologi diamati melalui observasi guru mereka. Pengamatan dilakukan berdasarkan kriteria minat literatur yaitu aktivitas siswa di waktu senggang seperti membaca, memiliki buku di rumah, senang membawa buku, membeli buku, frekuensi berkunjung ke perpustakaan, kemauan menceritakan kembali buku, menyukai buku tertentu, menyukai cerita tertentu, menyukai tema tertentu, dan kesan terhadap buku tersebut. Berdasarkan sepuluh kriteria yang diujikan, ditemukan sembilan poin menunjukkan sikap positif dan satu poin menunjukkan sikap negatif. Dengan demikian minat literatur siswa cukup baik. Selain itu, siswa lebih menyukai komik meskipun hanya beberapa yang senang menceritakan kembali isi buku tersebut. Hal tersebut dipengaruhi oleh kesulitan siswa dalam memetakan ide-idenya tentang cerita. Hal ini sangat krusial karena minat sastra harus membuat siswa mampu mengerjakan sesuatu berdasarkan hasil kegiatan membaca mereka (Rusyana, 1978).

Dalam kaitannya dengan kecerdasan ekologi, siswa diobservasi berdasarkan sebelas kriteria. Kriteria tersebut adalah tim kerja, kondisi kelas yang rapi, konsep membuang sampah pada tempat yang tepat, kondisi siswa di bawah meja, dan perhatian siswa terhadap jajan dan sampah, serta bekal makan siswa. dan memakannya, kemudian siswa menanam bertiga atau membuat poster, dan ajakan siswa kepada sesamanya untuk peduli lingkungan, dan menjaga diri, dan ada slogan di sekitar sekolahnya, serta penerapan reward atau punishment. Hasil penelitian menunjukkan bahwa sepuluh poin menunjukkan sikap positif dan satu poin menunjukkan sikap negatif. Dengan demikian dapat diartikan bahwa siswa secara umum memiliki kecerdasan ekologi (melalui bimbingan intensif). Bukti dari pernyataan ini didukung oleh tindakan siswa dalam menjaga diri sendiri berdasarkan bimbingan guru dan orang tua. Selain itu, sekolah juga memiliki andil besar dalam menumbuhkan kesadaran ekologis siswa. Mereka memberikan aturan sekolah seperti membuang sampah di tempat yang tepat, slogan, dan penghargaan / hukuman bagi siswa. Hal ini didukung oleh pernyataan Goleman (2009) yang membagi kesadaran ekologis menjadi tiga kategori, yaitu kognitif siswa terhadap masalah ekologi, tanggung jawab siswa terhadap lingkungannya, dan tindakan siswa dalam memberikan manfaat bagi lingkungannya. Mereka memberikan aturan sekolah seperti membuang sampah di tempat yang benar, slogan, dan penghargaan / hukuman bagi siswa. Hal ini didukung oleh pernyataan Goleman (2009) yang membagi kesadaran ekologis menjadi tiga kategori, yaitu kognitif siswa terhadap masalah ekologi, tanggung jawab siswa terhadap lingkungannya, dan tindakan siswa dalam memberikan manfaat bagi lingkungannya. Mereka memberikan aturan sekolah seperti membuang sampah di tempat yang benar, slogan, dan penghargaan / hukuman bagi siswa. Hal ini didukung oleh pernyataan Goleman (2009) yang membagi kesadaran ekologis menjadi tiga kategori, yaitu kognitif siswa terhadap masalah ekologi, tanggung jawab siswa 
terhadap lingkungannya, dan tindakan siswa dalam memberikan manfaat bagi lingkungannya.

\section{SIMPULAN}

Hasil penelitian menunjukkan minat sastra siswa kelas IV mengalami peningkatan (catatan: tidak menyukai kegiatan menceritakan kembali cerita dan memetakan ide cerita). Kecerdasan ekologi siswa juga dikembangkan (catatan: dalam proses bimbingan). Indonesia belum menyediakan buku sastra anak berbasis ekoliterasi, yang diwakili, untuk siswa kelas empat. Oleh karena itu diperlukan pengembangan buku. Buku sastra anak berbasis eko-literasi yang dikembangkan memiliki tiga poin utama. Pertama, buku tersebut memiliki ciri-ciri sebagai berikut, buku cerita bergambar, konten petualangan anak yang berkaitan dengan tema "Merawat Makhluk Hidup" berdasarkan kurikulum 2013 untuk siswa kelas IV. Kedua, Proses pengembangan buku sastra anak berbasis eko literasi mengikuti prosedur yang sistematis dan tidak terpisahkan antara satu urutan dengan urutan lainnya. Ketiga, desain akhir yang dihasilkan dalam penelitian ini adalah model buku sastra anak berbasis eko-literasi untuk siswa sekolah dasar. Judul bukunya adalah Misteri Hilangnya Seorang Teman, dan Misteri Si Kupu-Kupu. Buku ini dimaksudkan sebagai buku pendukung, khususnya tema 3 "Peduli Terhadap Makhluk Hidup" di kelas IV SD dengan kurikulum 2013.

\section{DAFTAR PUSTAKA}

Abdurrohim, I. (2016). Pengembangan Ekoliterasi Siswa Dalam Mengantisipasi Polusi Udara Melalui Pemodelan Keterampilan Sosial Dalam Pembelajaran Ips (Disertasi Doktor, Universitas Pendidikan Indonesia).

Akker, J. (1999). Prinsip dan Metode Penelitian Pembangunan. London: Penerbit Akademik Kluwer.

Akker, J. et al., (2006). "Memperkenalkan Riset Desain Pendidikan", dalam Riset Desain Pendidikan. New York: Routledge.

Baswedan, AR (2014). Gawat Darurat Pendidikan di Indonesia. Paparan Presentasi. Menteri Pendidikan dan Kebudayaan disampaikan dalam Silaturahmi Kementerian dengan Kepala Dinas. Jakarta, 01 Desember 2014.

Carver, RL (1996). "Teori untuk praktek: Sebuah kerangka berpikir tentang pendidikan pengalaman". The Journal of Experiential Education, 19 (1), 8-13.

Carver, RL (1997). "Dasar-dasar teoretis dari pembelajaran layanan". Theory into Practice, Volume 36 (No. 3), halaman 143-149.

Corney, G. \& Reid, A. (2007). "Pembelajaran siswa guru tentang materi pelajaran dan pedagogi dalam pendidikan untuk pembangunan berkelanjutan". Environmental Education Research, Volume 13 (No.01), halaman 33-54.

Denny, JA (11 Januari 2017). Peminat yang membaca karya sastra Indonesia hanya mencapai 6,2 persen. Diakses tanggal 2 Februari 2018 darihttp: ///www.antaranews.com.

Goleman, D. (2009). Kecerdasan ekologis: bagaimana mengetahui dampak tersembunyi dari apa yang kita beli dapat mengubah segalanya. Buku Broadway.

Hasanuddin. (2015). Sastra Anak: Kajian Tema, Amanat dan Teknik Penyampaian Cerita Anak Terbitan Surat Kabar. Bandung: Angkasa.

Program Penilaian Nasional Indonesia (INAP). (2016). Data Satistik Kemampuan Anak Indonesia. Tersedia [online] puspendik.kemdikbud.go.id

Program Penilaian Nasional Indonesia (INAP). (2018). Laporan Hasil Tes INAP 2016. Direktorat Pembinaan Sekolah Dasar, Direktorat Jendral Pendidikan Dasar dan 
Menengah, Kementerian Pendidikan dan Kebudayaan.

lovino, S. (2012). Tinjau Esai: Langkah Menuju Ekokritisme Material. Literatur Terkini tentang "Materialisme Baru" dan Dampaknya pada Teori Ekokritikal. Ecozon @ : Jurnal sastra, budaya dan lingkungan Eropa, 3 (1).

Lanter, E., Watson, LR, Erickson, KA, \& Freeman, D. (2012). Keaksaraan yang muncul pada anak autis: Eksplorasi proses dinamis perkembangan dan kontekstual. Layanan bahasa, pidato, dan pendengaran di sekolah.

Lidinillah, DAM (2011). Penelitian Desain Pendidikan: Kerangka Teoritis untuk Tindakan. [On line]. Tersedia di http://file.upi.edu/Direktori/KDtasikmalaya/dindin_abdul_muiz_lidinillah_(kd tasikmalaya). Diakses 12 Oktober 2017.

Nugraha, RG (2015). Meningkatkan ekoliterasi siswa SD melalui metode field trip kegiatan ekonomi pada mata pelajaran ilmu pengetahuan. Mimbar Sekolah Dasar, 2 (1), 60-72.

Polkinghorne, DE (1995). Konfigurasi naratif dalam analisis kualitatif. Jurnal internasional studi kualitatif dalam pendidikan, 8 (1), 5-23.

Rusyana, Y., dkk. (1978). Metode Pengajaran Sastra. Bandung: IKIP.

Supriatna, N. (2016). Ecopedagogy: Membangun Kecerdasan Ekologis dalam Pembelajaran IPS. Bandung: PT Remaja Rosdakarya.

Ward, B. \& Dubos, R. (1972). Hanya Satu bumi. London: Penguin (Paperback). 